\title{
\begin{tabular}{llllllllllllllllll}
$E$ & $S$ & $S$ & $E$ & A & $\mathbf{N}$ & $\mathbf{D}$ & $\boldsymbol{E}$ & $\boldsymbol{S}$ & $\boldsymbol{S}$ & $\boldsymbol{E}$ & $\boldsymbol{T}$ & $\boldsymbol{A}$ & $\boldsymbol{N}$ & $\boldsymbol{T}$ & $\boldsymbol{U}$ & $\boldsymbol{M}$ \\
\hline
\end{tabular} \\ ROCZNIKI FILOZOFICZNE \\ Volume LXVII, issue $4-2019$ \\ DOI: https://dx.doi.org/10.18290/rf.2019.67.4-1
}

GYULA KLIMA

\section{AQUINAS'S REAL DISTINCTION AND ITS ROLE IN A CAUSAL PROOF OF GOD'S EXISTENCE}

Since I basically agree with everything Gavin Kerr had to say in his book, this paper is not going to offer any criticism of the way he treats Aquinas' argument. Instead, this paper offers an alternative way of reconstructing Aquinas' argument, intending to strengthen it especially in those controversial aspects of it that Kerr's reconstruction left untreated or in relative obscurity. Accordingly, although my treatment will have to have some overlaps with Kerr's (such as my response to Kenny's critique of Aquinas), it will deal with issues essential to adequate replies to certain competent criticisms of his argument untreated by Kerr (such as Buridan's critique). For the sake of the "formally inclined" reader, my treatment will also include an Appendix offering a formal reconstruction of both the main argument and its subarguments to demonstrate the formal rigor of Aquinas' original.

Since Aquinas' argument would obviously fall under what Kant called a "cosmological argument," we should start its discussion with clarifying what a cosmological argument is and what the most vulnerable aspects of this type of argumentation can be.

A "cosmological argument" is one that argues from the obvious existence of something other than God for the existence of God as its first efficient cause. This sort of reasoning can be vitiated by two main types of objection. The first, which I will refer to as the "self-sufficiency objection," argues that the obvious existence of the thing the cosmological argument refers to does

Gyula Klima, PhD — Professor of Philosophy at Fordham University, New York, NY, USA; address for correspondence — e-mail: gyula.klima@gmail.com; ORCID: https://orcid.org/00000002-1597-7039. 
not need an explanation in terms of an efficient cause: it just exists, and there is no need for an efficient cause for its existence (see for instance the objections to Aquinas' First Way from the Newtonian idea of inertial motion). The second type of objection, which I will refer to as the "infinite regress objection," argues that even if the obvious existence of the thing in question does need an efficient cause to sustain it, that cause need not be God, but may be an entity other than God, which in turn can also be caused by something other than God, and so on, to infinity, without ever needing a First Cause, which one might plausibly identify with God. In this paper, I will argue that Aquinas' thesis of the real distinction of creatures and the identity thereof in God plausibly takes care of both types of objections, provided we have a proper understanding both of the thesis itself, and its import on the notion of efficient causality. So, I will start the discussion with the thesis of real distinction, in particular, with Aquinas' famous argument for it in his De Ente et Essentia, and then I will consider how this thesis is "cashed out" in the causal proof for the existence of God in the same passage.

\section{THE CRITIQUE OF KENNY'S CRITIQUE \\ OF THE “INTELLECTUS ESSENTIAE” ARGUMENT}

Aquinas' famous intellectus essentiae argument in his De Ente et Essentia is taken by some of his modern commentators, most notably, by Anthony Kenny, to be one of Aquinas' most serious attempts to prove his fundamental metaphysical thesis of the real distinction of essence and existence in creatures. But, in fact, this argument is only a part of a larger argumentation, which as a whole intends to prove the real distinction of essence and existence in creatures and the identity thereof in God. Thus, the intellectus essentiae argument in itself only attempts to prove the real distinction between essence and existence at least in some obvious cases, which then is the starting point of the larger argumentation for the entire thesis. For the larger argumentation seeks to establish that if essence and existence are identical in some case, then they can be identical only in a unique case, from which then it follows that they must be distinct in everything else. Finally, from the real distinction thus established in everything else, the argument argues that the obvious existence of these things entails the actual existence of that unique cause of their existence in which essence and existence are not distinct, namely, the existence of God. 
So, let us first deal with the intellectus essentiae argument, which is embodied in the following couple of lines in Aquinas' text:

Whatever is not included in the understanding of an essence or quiddity is coming to it from outside, entering into composition with the essence; for no essence can be understood without its parts. But every essence can be understood without knowing about its existence, for I can understand what a man or a phoenix is, and not know whether it actually exists in the nature of things. Therefore, it is clear that existence is distinct from essence, unless, perhaps, there is a thing whose quiddity is its own existence. ${ }^{1}$

In his controversial book, Aquinas on Being, ${ }^{2}$ Anthony Kenny launched a two-pronged attack against Aquinas' argument.

On the first prong, he tried to establish that if Aquinas in this argument was talking about existence in the sense of "specific existence," expressed by the Fregean existential quantifier, then he was either talking nonsense or essence and existence are distinct both in God and in creatures. Kenny's reasoning is based on the idea that Aquinas' argument can plausibly be understood as claiming in its premises that while we know, for instance, what is meant by the word 'phoenix,' namely, a mythical bird that sometimes bursts out in flames and is later reborn from its ashes, we just do not know if there is such a thing, i.e., we do not know if the word is true of something. Indeed, we actually know that the word 'phoenix' is not true of anything, for nothing is a phoenix, which is precisely the Fregean quantificational interpretation of the notion of existence. However, as Kenny correctly concludes, on this interpretation Aquinas' argument would either amount to nonsense or it would prove too much. For on this understanding of the notion of existence, the thesis of the real identity of God's essence and existence would amount to something like the ungrammatical gibberish: "God's essence is $\exists$." On the other hand, if we assume that the argument is not nonsensical and works, then it must work in the same way for the term 'God' as it does for the term 'phoenix'. But then the argument proves too much, for then, in the same way, we know what the term 'God' means, but we do not know whether it is true of anything, for we do not know whether there is a God. Thus, if this is what the distinction of essence and existence means, then they are distinct in God just as well as they are in creatures.

\footnotetext{
${ }^{1}$ Thomas Aquinas, "On Being and Essence," c. 5, in Medieval Philosophy: Essential Readings with Commentary, ed. Gyula Klima (Blackwell Publishers, 2007), 240.

${ }^{2}$ Anthony KenNy, Aquinas on Being (Oxford: Oxford University Press, 2002).
} 
On the other prong of his attack Kenny argues that if Aquinas was talking about existence in the sense of "individual being," meaning actuality, corresponding to the Fregean notion of Wirklichkeit, then essence and existence are identical both in God and in creatures. For then we have to say that just as for God to be actual is for Him to be God, so for a dog, say, Fido, to be actual is for Fido to be a dog. Therefore, if this is what the identity of essence and existence means, then Fido's essence is just as identical with his existence as God's essence is with His existence.

Thus, Kenny concludes, either way, the intellectus essentiae argument fails to establish Aquinas' desired conclusion. However, as I have argued in detail elsewhere, ${ }^{3}$ Kenny's objection fails on several counts.

In the first place, Aquinas simply does not have a notion equivalent to the Fregean notion of an existential quantifier. In fact, a notion that would come closest to this notion in Aquinas' conceptual arsenal would be regarded by him not as a concept of existence, but as a signum quantitatis, namely, a signum particulare, the syncategorematic concept expressed by the Latin terms 'quidam', 'aliquid' or their equivalents, which render a proposition to which they are prefixed a particular, as opposed to a universal, singular or indefinite proposition (as in, 'Quidam homo est animal' = 'Some man is an animal', as opposed to 'Every man is an animal', 'Socrates is an animal' or 'A man is an animal', respectively). In any case, Kenny's reason for holding that Aquinas would have to use in his argument the notion of specific existence, and, correspondingly, the notion of nominal as opposed to real essence, ${ }^{4}$ is his unjustified assumption that Aquinas would take a phoenix by definition to be a fictitious bird as we do. However, from his argument, as well as from the parallel text of his Commentary on the Sentences (In II. Sent., d. 3, q. 1, a. 1, co.), it is quite clear that Aquinas uses this example as the illustration of a real, but ephemeral natural phenomenon, like a lunar eclipse or a rain-

\footnotetext{
${ }^{3}$ Gyula KLIMA, "On Kenny on Aquinas on Being: A critical review of Aquinas on Being by Anthony Kenny," feature review in International Philosophical Quarterly 44 (2004): 567-580.

${ }^{4}$ A nominal essence is what is described by a nominal definition, which merely provides the meaning of a name, regardless of whether there is or even just can be anything that fits that description, while a real essence is what is signified by a real or quidditative definition, which identifies the essential features of the thing that is referred to by a name according to the meaning specified by the corresponding nominal definition. Therefore, we can have nominal essences expressed/described by nominal definitions even of non-entities or mere impossibilia, whereas real essences can only be had by really existing genuine entities. For a good description of the contrast between nominal and quidditative definitions in the Thomistic tradition, see THOMAS DE VIO Cardinalis Cajetanus, "Super Librum De Ente et Essentia Sancti Thomae," in IDEM, Opuscula Omnia (Bergomi: Typis Comini Venturae, 1590), 299.
} 
bow, the essence of which we could know perfectly well in terms of a scientific definition without knowing whether this kind of thing actually exists at the present time. So, Kenny's objection definitely fails on the first prong, on account of simply missing Aquinas' point in the argument, taking it to deal with nominal, rather than real essences, and operating with a notion of existence that is alien to Aquinas' thought.

But Kenny's objection fails on its second prong as well, even if the interpretation it involves is somewhat closer to Aquinas' original intention. For Kenny bases his objection on the false assumption that the distinctness of essence and existence would have to mean that it is possible to have one without the other. And so, he argues, since it is impossible to have a dog's existence without its essence - for a dog cannot be without being a dog - essence and existence would have to be the same also in the case of this creature. However, this assumption is obviously false: for it is clearly possible to have distinct, yet necessarily co-occurring items in reality. For example, it is clear that the triangularity of any particular triangle (its having three angles) is not the same as its trilaterality (its having three sides), unless sides and angles are the same items. But it is also clear that one cannot have a particular triangularity without a particular trilaterality. So, we have two really distinct items here, which are nevertheless inseparable in reality. Again, this particular material form, say, the substantial form of this particular block of wood, cannot exist without the matter it informs, and the matter it informs cannot exist (at least on Aquinas' conception), without this form actually informing it (since for both of them to be is nothing but for this particular block of wood to be). Still, Aquinas would take this form and this matter to be really distinct items in reality, since they are precisely those mutually exclusive, non-overlapping, essential parts of the substance of this block of wood into which it has to be analyzed in Aristotle's hylomorphist metaphysics. Therefore, pace Kenny, real distinction does not have to mean real separability, which finishes off the other prong of his attack.

\section{RECONSTRUCTING THE ARGUMENT}

Accordingly, to avoid the misunderstandings involved in Kenny's criticism, we have to understand the argument as dealing with real, individualized essences, and arguing for their real, mind-independent distinction from real, individual acts of existence at least in those cases in which we 
have knowledge of the essence without knowing whether it is actually present in any actually existing individual.

Therefore, taking $\mathrm{c}$ to be any arbitrarily chosen thing whose nature is known but whose existence is not known, the gist of the argument may be reconstructed as follows:

1. The nature of $\mathrm{c}$ is known.

2. The existence of $\mathrm{c}$ is not known.

3. Therefore, the nature of $\mathrm{c}$ is not the existence of $\mathrm{c}$.

In fact, if we name the individualized nature of $\mathrm{c}$ by the proper name ' $\mathrm{n}$ ', and its individualized act of existence by the proper name 'e', then this argument may be regarded as an instance of the following valid argument form of predicate logic:

1. $\mathrm{Kn}$

2. $\sim \mathrm{Ke}$

3. $\mathrm{e} \neq \mathrm{n}$

Accordingly, in this reconstruction, the argument is certainly immune to Kenny's criticism; indeed, it may appear to be absolutely uncontroversial.

\section{BURIDAN'S CRITICISM AND A THOMISTIC REPLY}

However, John Buridan attacked the argument precisely in this reconstruction, on account of the logical peculiarities of the intentional verb it involves.

Buridan takes on Aquinas' argument in his Questions on Aristotle's Metaphysics. In the first place, in the following passage he reconstructs the argument precisely in the way I presented it above, as an objection to his own position, which he is going to answer after his own determination of the issue:

... I can have scientific knowledge of roses or thunder, and yet I may not know whether there is a rose or whether there is thunder. Therefore, if one of these is known and the other is unknown to me, then it follows that the one is not the same as the other. ${ }^{5}$

\footnotetext{
${ }^{5}$ JohanNis BuRIDANi Quaestiones in Aristotelis Metaphysicam: Kommentar zur Aristotelischen Metaphysik (Paris, 1518; reprint, Frankfurt am Main: Minerva, 1964), selections from lb. 8, q. 4, emended ad sensum and translated by Gyula Klima, in Medieval Philosophy: Essential Readings with Commentary, ed. Gyula Klima (Blackwell Publishers, 2007), 250.
} 
It is noteworthy in this reconstruction that Buridan is absolutely clear on the point of the argument Kenny missed, namely, that it is to prove the thesis of real distinction concerning the real essences of scientifically known but ephemeral natural phenomena, whose actual existence may not be known at any given time despite our scientific knowledge of their nature.

Buridan's criticism is based on the well-known phenomenon of the breakdown of the principle of the substitutivity of identicals in intentional contexts.

After all, I can clearly know something qua $\mathrm{F}$ and not know it qua $\mathrm{G}$, even if it is both F and G, for I simply don't know that this F is also a $\mathrm{G}$.

Thus, it seems that as long as we can know the same item qua some essence, but not qua some act of existence, it is quite possible for us to know the essence of a certain thing without knowing whether it exists or not, despite the fact that its essence and existence are the same. Therefore, Aquinas' argument fails to establish its desired conclusion, the real distinction of the essence and existence of a thing on the basis of the fact that we may know its essence without knowing its existence. ${ }^{6}$

But this does not have to be the end of the story for Aquinas. In fact, if we take a closer look at Aquinas' actual formulation of the argument, we have to notice something that is entirely neglected in the version of it criticized by Buridan; namely, Aquinas' talking about "parts of the essence" without which it cannot be understood. What can he possibly mean by this? And what is the relevance of this to the validity of his argument?

Since according to Aquinas the essence or quiddity of a thing is what is signified in it by its quidditative definition ${ }^{7}$ and the essence of a thing in and of itself is not a conglomerate of several distinct items, by "the parts of its essence," he means whatever is signified precisely by the parts of the quidditative definition of the thing. ${ }^{8}$ In fact, since on his interpretation the definition is not primarily a linguistic expression, but an intention, that is, a concept of the mind expressed by the corresponding linguistic expression ren-

\footnotetext{
${ }^{6}$ For a detailed account of Buridan's objection, along with an explanation of its theoretical background, see the original paper from which the present first part of this paper derived: Gyula KlimA, "Aquinas vs. Buridan on Essence and Existence, and the Commensurability of Paradigms," in Metaphysics: Aristotelian, Scholastic, Analytic, ed. Lukáš Novák, Daniel D. Novotný, Prokop Sousedik, and David Svoboda (Ontos Verlag: Heusenstamm, 2012), 169-184.

${ }^{7}$ See the end of c. 1 of De Ente et Essentia. The quidditative definition of the thing Aquinas has there in mind is the definition of its most specific species consisting of its proximate genus and its specific difference.

${ }^{8}$ For this point see for instance the entire discussion of c. 4 of his De Ente et Essentia.
} 
dering this expression meaningful, we can say that on Aquinas' conception having scientific, quidditative knowledge about a thing is having in mind its quidditative concept, expressible by a scientific, quidditative definition. In this context, therefore, we need to distinguish between merely having some (no matter how vague and confused) concept of a thing, resulting from the mind's first, spontaneous abstractive act, and having its quidditative concept, which is a clear and distinct, articulate concept, resulting from scientific inquiry into the nature of the thing. ${ }^{9}$ Having this sort of quidditative concept, therefore, means clearly knowing its implications: for instance, if I have the clear and distinct quidditative knowledge of diamonds as being tetrahedrally crystallized pieces of carbon, then on account of having that concept, as well as the concept of electric conductivity, I know just as well that diamonds are poor conductors (as opposed, say, to graphite).

Now what does all this mean concerning the validity of Aquinas' argument and its Buridanian criticism? Concerning Buridan's criticism we should note that the breakdown of the substitutivity of identicals in intentional contexts is conditioned on the logical independence of the concepts in terms of which one and the same thing is conceived, known or understood. This is why it is possible for me to know, e.g., my father, and not to know the man approaching, even if the man approaching is actually my father. For I may certainly have the recognition of him in terms of the concept whereby I conceive of him as my father, while lacking the recognition of him insofar as I merely cognize him as the man approaching (insofar as 'having the recognition' of this person would mean being able to give an adequate answer to a question asking about the identity of this person). But this is so because the two acts of cognition in question are logically independent, whence I may perfectly well have the one without the other.

However, if the concepts or acts of cognition are not logically independent, whence I cannot have the one without the other, then the situation is radically different. If I have the scientific concept of a rainbow, say, as being the refraction of light on water suspended in air, then I cannot know a rainbow qua rainbow, without knowing it at the same time qua the refraction of light on water suspended in air. To be sure, before forming the scientific concept, I can certainly have some vague and confused knowledge of it as some colorful arch in the sky, without knowing it qua the refraction of light

\footnotetext{
${ }^{9}$ For a painstaking and extremely illuminating discussion of distinct versus confused concepts or acts of cognition, see q. 1 of Cajetan's question commentary on Aquinas' De Ente et Essentia.
} 
on water suspended in air. However, once I have formed its quidditative concept, I cannot have knowledge of the same thing without knowing the implications of its quidditative concept.

But then the situation would have to be similar with the notions of essence and existence, provided we are talking about the clear and distinct scientific understanding of a thing's essence, which involves having the articulate, quidditative concept of the thing, and knowing its logical implications. For in this situation, if the existence of the thing were the same as the essence of the thing, or, using Aquinas' phrase, if it were "a part of" the essence of the thing, then this would mean that having the quidditative cognition of the thing would entail also having its cognition in terms of its existence: that is to say, we could not have its quidditative knowledge without knowing that it actually exists. Indeed, this is precisely what Aquinas hypothetically concedes in the conclusion of his argument:

Therefore, it is clear that existence is distinct from essence, unless, perhaps, there is a thing whose quiddity is its own existence.

That is to say, if there is a thing whose essence and existence are the same, then having a clear and distinct cognition of the thing's essence would immediately give us the knowledge that the thing actually exists, which is the exact reason why Aquinas would say that although God's existence is self-evident in itself, that is, it would be knowable a priori by anyone with a clear and distinct cognition of divine essence, still, it is not self-evident $t o$ $u s$, namely, human beings in our natural state, for in this state we just cannot have the clear and distinct cognition of divine essence that would allow us to realize the self-evident character of His existence. ${ }^{10}$ This is precisely why we need an a posteriori, causal proof for His existence from the existence of those things whose existence is evident to $u s$, His creatures.

\section{THE "COSMOLOGICAL PROOF”}

However, even if the existence of God's creatures is quite evident to us, it is not so evident that they are God's creatures at all, namely, that their existence even calls for a cause to sustain it, and that ultimately that sustaining cause has to be the cause of all creation, namely, God. To establish these points in terms of a proper understanding of Aquinas' Aristotelian notion of efficient causality, we need a little background.

\footnotetext{
${ }^{10}$ Thomas Aquinas, Summa Theologiae I, q. 2, a. 2.
} 
Aquinas, in his brilliant, succinct summary of Aristotle's doctrine, De Principiis Naturae, distinguishes (among others) the following modes of efficient causes: some are actual causes, others are potential; again, some are per se, others per accidens; again, some are particular, others are universal; and finally some are proximate, and others are remote.

The first distinction, between actual and potential causes, distinguishes an agent that merely has a certain capacity to act in a certain way from an agent that is actively using that capacity in actual operation. For instance, a doctor on vacation is a merely potential cause with regard to healing, for even then he can heal, but does not. By contrast, the same doctor actually practicing his art of medicine is an actual cause, actively exercising his ability to heal.

The second distinction, between per se and per accidens causes distinguishes between how various causes are conceived, and are accordingly denominated, in a particular causal relation. For instance, if our doctor also happens to be a pianist (think Albert Schweitzer), then of course a patient whom he has just cured can truthfully say that a pianist cured her, but everybody would assume that it is a mere coincidence that the person who cured her happened to be a pianist, for it was not by his music that he cured her. Or, conversely, a concert goer can truthfully say that at the concert a doctor played the piano, nevertheless, everybody would take it to be a mere coincidence that the pianist happened to have a medical degree, as it is causally irrelevant to his musical abilities. Again, when I see a sugar cube, I certainly see a sweet thing and when I taste it, I taste a white thing, but of course in these examples, the features whereby I perceive it (i.e., whereby it affects my senses causing its perception) are not the features whereby it is denominated: it is not its taste that affects my sight and it is not its color that affects my taste. In short, in these cases, the same cause is denominated in terms of its merely coincidental, in the given causal relationship causally irrelevant features, thus, in these cases we have described per accidens causes. By contrast, if I say that I see a white thing or I taste a sweet thing, then I am denominating the cause of my perceptions from its causally relevant features; thus, I am describing per se causes. In general, in a given causal relation, an efficient cause is conceived and denominated as the non-coincidental, per se cause of its per se effect, if in that causal relation both the cause and the effect are denominated in terms of their causally relevant features (active and passive powers, if we are denominating potential causes, and actual actions and passions, if we are denominating actual causes), otherwise the cause and the effect are denominated as per accidens or coincidental cause and effect. 
Now, since the agent or efficient cause is what actualizes its effect and the patient is its effect getting or being actualized, there are four important conclusions that immediately follow from this description.

First, the coincidence of per se and per accidens causes: since this is a distinction made in terms of how something is conceived and accordingly denominated, the same thing in the same causal relation can be denominated either as a per se or as a per accidens cause, depending on whether it is denominated in terms of its causally relevant feature or not, as should be clear even from the examples.

Second, the necessity of per se causality: since the agent is a thing that has an active power (an ability to act), on account of which it is capable of bringing into actuality something, the patient, in some respect, namely, in that respect in which it is in potency to become actual, the action of the agent and the actualization of the patient are the same process; as Aquinas put it: “... action and passion are not two motions, but they are one and the same motion: for insofar as it is from the agent, it is said to be action, and insofar as it is in the patient, it is said to be passion." ${ }^{11}$ But then, if the act of the agent as such and the act of the patient as such are one and the same in reality, but distinct only as to how they are conceived, then the one cannot be without the other in reality, even if the one can be conceived without it being conceived as the other: for one and the same thing cannot be there and not be there, no matter how it is conceived; therefore, the act of the per se cause cannot be there without the act of the per se effect, that is to say, the per se effect of a per se cause has to be there as long as the agent is acting and the patient is receiving its action, for the action and the reception are one and the same process of actualization inherent in the patient, coming from the agent. For example, there is illumination if and only if an illuminating thing actually illuminates a thing being illuminated. Clearly, a no matter how luminous thing is not an illuminating thing unless it illuminates something and an illuminable thing is actually illuminated only if an illuminating thing actually illuminates it: illuminans illuminat illuminatum - what can be more necessary than this?

The third conclusion is the irreflexivity of per se causality; this is actually Aquinas' sub-argument in his First and Second Ways of proving God's existence in the Summa Theologiae, although he fails to mention that this

11 “... actio et passio non sunt duo motus, sed unus et idem motus: secundum enim quod est ab agente dicitur actio, secundum autem quod est in patiente dicitur passio." In Phys., lib. 3 1. 5 n. 7. 
conclusion and the reasoning backing it up concern only per se causes and effects (because the prospective theology students for whom he wrote his textbook could reasonably be expected to know this, as opposed to modern scholars, leading to a number of futile objections in the contemporary secondary literature). Since the per se agent or efficient cause is active, i.e., is in actuality in precisely that respect in which the per se patient is passive, i.e., in potentiality or in a state of being receptive of the agent's action, one and the same thing cannot be the per se cause of itself, for that would mean that it would have to be agent and patient, active and passive, i.e., actual and potential in the same respect and in the same way, which is impossible, for then it would have to be and not be in the same respect, which is an explicit contradiction.

The fourth conclusion is the non-circularity and linear hierarchy of a series of per se, actual causes. The non-circularity of a series of per se causes is a direct consequence of the irreflexivity and transitivity of per se causation: suppose $\mathrm{A}$ is the per se cause of $\mathrm{B}$, and in turn, $\mathrm{B}$ is the per se cause of A, constituting circularity. But then, by transitivity (which is generally assumed in any form of causation), A would have to be the per se cause of A, which contradicts the irreflexivity of per se causation just proved. Therefore, per se causes and their per se effects have to be arranged in a linear, but possibly branching ordering, insofar as a cause of a cause of an effect can also be the cause of another cause and, through that, also the cause of another effect, as for instance the same transformer house can power the pair of wires lighting up this light bulb here, and through a switchboard can also power another pair of wires lighting up a light bulb in the next room. In fact, this idea of a linear arrangement of per se efficient causes in a possibly "downward branching tree structure" is the rationale for Aquinas' remaining two distinctions between the different modes of causes mentioned earlier.

Thus, the third distinction mentioned above, namely, that between proximate and remote causes should be pretty obvious, once we realize that the relation of per se efficient causality, on account of its necessary transitivity and irreflexivity, and on account of the fact that everything is either a cause or the effect of something else in the universe (for whatever is causally disconnected is not in this universe) provides a total ordering of all things in this universe, such that in every per se causal relationship everything is either an effect and not a cause (i.e., an ultimate effect) or both an effect and a cause (i.e., it is in intermediary cause), or, possibly, a cause of some further effect, but not an effect of anything (i.e., a first cause) in that particular 
per se causal relationship. That is to say, if its power to bring about or sustain its per se effect is insufficient on its own account, then an agent producing its per se effect must receive the energy it is missing from another cause, acting as an intermediary cause, channeling, as it were, that is, receiving, transforming and transmitting the power it receives from its cause, which therefore will be the proximate cause of this intermediary cause and the remote cause of the intermediary cause's effect. For example, if the illumination of the screen in a classroom at Fordham is the proximate effect of its proximate cause, namely, the overhead projector (to be properly denominated as "the illuminator," insofar as it is the per se cause of this particular effect, namely, of the screen being illuminated), then the transformer house on campus powering the illuminator is its remote cause. In fact, it is its actual remote cause, which is shown by the fact that if the transformer house stopped operating, that is to say, if the projector stopped being powered, then it would cease to operate as well, and its effect, the illumination of the screen, would go out of existence as well, that is, the screen would immediately go dark. And, of course, the transformer house is a per se actual cause only insofar as it is denominated from its causally relevant feature, namely, supplying electric power for the working of the projector, i.e., a power supply. But these considerations concerning the ordering of actual per se causes immediately give rise to the idea of a vertical hierarchy of causes, in which the more remote cause is somehow more powerful, and whose causality therefore extends to more than one intermediary cause in more than one chain of simultaneously co-acting causes, just as the transformer house powers not just the projector, but also the light and the computers, and the power plant in Niagara Falls powers not just this transformer house on Fordham's campus, but many others all over New York City, which would apparently be a nice modern illustration of Aquinas' lastly mentioned distinction.

And that would be the fourth distinction, namely, that between more or less universal and particular causes. However, I believe one should be careful in the interpretation of this distinction. In the first place, a universal cause as Aquinas thinks about it, is certainly not a universal in its being (given that Aquinas rejects Platonic universals), but in its causality: a particular cause is the cause of only this particular effect, whereas a universal cause is a cause of several particulars of a given kind. However, an immediate consequence of this interpretation and the above-demonstrated irreflexivity of per se efficient causality is that a universal cause of a given kind of particulars cannot be of the same kind; for otherwise, being the cause of all 
particulars of the same kind, it would have to be a cause of itself, which is impossible. Therefore, the universal cause of a species cannot be a member of the same species: it has to be a non-univocal cause, that is to say, the form by virtue of which it acts and produces and/or sustains its effects is not the same form that it brings about in its effects.

This is the reason that by talking about more or less universal causes, which Aquinas also explicitly identifies with more or less remote causes, he means not only that the causality of a more universal cause extends to more kinds, but also that the reason why its causality covers more kinds of effects is that it is causing them in a more universal respect: it has a power and a corresponding activity that can be received in so many different ways by different kinds of recipients, as the radiation of the sun received as heat in water powers the water cycle around the globe, while received in the chloroplasts of plants, it powers (most of) the biosphere. In fact, this is the rationale (and not some ancient superstition) for one of Aquinas' favorite quotes from Aristotle's Physics: homo generat hominem et sol - man is generated by man and the sun, ${ }^{12}$ which without the insights of modern thermodynamics and ecology would sound like something coming from some totally unscientific, superstitious, astrological speculations about the mysterious influence of celestial bodies on our lives.

But this remark should also give us an opportunity to reflect on the stark contrast between the early modern, mechanistic and the Scholastic-Aristotelian non-mechanistic notions of efficient causality. For in contemporary natural science, the idea of causality is no longer based on the Humean paradigm case of one billiard ball knocking into motion another, indeed, in general, it is no longer the idea of diachronic event-patterns that is the prevailing idea of causation, although it still is in many philosophical speculations (see "how mental events can cause physical events and vice versa"); rather, the more and more prevailing notion, especially in the intriguingly related fields of ecology, thermodynamics and information theory, is the idea of the synchronic channeling of the flow of energy and information among systems of various scales and their subsystems. However, that idea is precisely the scholastic idea. Consider Aquinas' general description of the notion of a cause: "a cause is from the being of which there follows [the being of] something else." 13

\footnotetext{
${ }^{12}$ SCG, lib. 3 cap. 69 n. 24; ST I, q. 115 a. 3 ad 2; QDP, q. 3 a. 7 s.c. 3, etc.

13 "Causa est ex cuius esse sequitur aliud." DPN c. 3.
} 
Now, if we add to this that the notion of being for Aquinas is not just the static modern idea of "being an element of the universe of discourse," but the dynamic notion of being the actuality of all forms, where the notion of actuality is that of being in act, being active, being at work, which in Aristotle's Greek would be the idea of being in energeia, i.e., in a state of energy, then we should not be surprised at the idea that our modern notions of energy and information will bear some striking resemblances to Aquinas' dynamic notions of being as act, and of form as that which informs, as that which determines the various ways in which things are, can be, and can be active or receptive, informing others and receiving information from others.

But then, looking at the being or actual existence of things in this way, and noticing that the things we are familiar with in our experience tend to go out of existence unless they receive the sustaining energy input of others, and looking into some details of how the being or so-being of things is the result of various chains of co-active, per se, actual causes that are necessarily arranged in a hierarchy of increasing universality, then we can appreciate Aquinas' idea that even if it may seem a logical possibility that such a chain of causes should go to infinity without there being an absolute first, uncaused cause, it is not a physical possibility, for two reasons: first, if all causes are intermediary causes, then they all are just a series of receivers, transformers and transmitters of energy and information, without any ultimate source for that energy and information, i.e., they have nothing to receive, transform and transmit; and second, in the series of per se causes those higher up are more universal than those lower down; however, since there is a most universal form of energy or actuality, namely, the very being of anything, there must be a most universal cause of the causality and being of all others, ${ }^{14}$ which itself is not in any need of a further source of energy for its own being, because it is just esse ipsum subsistens. To be sure, with this idea we leave the realm of physics; however, and that is Aquinas' point, it is our ordinary physics, if understood well, that demands it. But knowing this much, and knowing that there can be only one thing whose essence is identical with its existence, we also know that everything else must depend for its existence on the simultaneous creative activity of their ultimate cause, creator omnium, that is, God. ${ }^{15}$

\footnotetext{
${ }^{14}$ For this idea, check QDP q. 7, a. 2.

${ }^{15}$ For more details of my comparisons of the rather different notions of efficient causality in Scholastic Aristotelian and modern philosophy, see the original paper from which the second half of this paper is derived: Gyula KuImA, "Whatever Happened to Efficient Causes?," in Skepticism,
} 


\section{BIBLIOGRAPHY}

BurIDANUS, Johannes. Quaestiones in Aristotelis Metaphysicam: Kommentar zur Aristotelischen Metaphysik. Paris, 1518; reprint, Frankfurt am Main: Minerva, 1964,

Kenny, Anthony. Aquinas on Being. Oxford: Oxford University Press, 2002.

KLimA, Gyula. "Aquinas vs. Buridan on Essence and Existence, and the Commensurability of Paradigms.” In Metaphysics: Aristotelian, Scholastic, Analytic, edited by Lukáš Novák, Daniel D. Novotný, Prokop Sousedík, and David Svoboda, 169-184. Heusenstamm: Ontos Verlag, 2012.

KlimA, Gyula. "On Kenny on Aquinas on Being: A critical review of Aquinas on Being by Anthony Kenny," feature review in International Philosophical Quarterly 44 (2004): 567-580.

KLima, Gyula. "Whatever Happened to Efficient Causes?" In Skepticism, Causality and Skepticism about Causality, edited by Gyula Klima and Alexander W. Hall, 31-42. Proceedings of the Society for Medieval Logic and Metaphysics, Vol. 10. Cambridge: Cambridge Scholars Publishers, 2013.

Medieval Philosophy: Essential Readings with Commentary, edited by Gyula Klima. Blackwell Publishers, 2007.

Thomas Aquinas, “On Being and Essence.” In Medieval Philosophy: Essential Readings with Commentary, edited by Gyula Klima, 227-249. Blackwell Publishers, 2007.

Thomas de Vio Cardinalis Cajetanus. "Super Librum De Ente et Essentia Sancti Thomae." In IDEM. Opuscula Omnia, 292-376. Bergomi: Typis Comini Venturae, 1590.

\section{AQUINAS'S REAL DISTINCTION AND ITS ROLE \\ IN A CAUSAL PROOF OF GOD'S EXISTENCE}

\section{S u m m a r y}

This paper is not going to offer any criticism of the way Gaven Kerr treats Aquinas' argument. Instead, it offers an alternative way of reconstructing Aquinas' argument, intending to strengthen especially those controversial aspects of it that Kerr's reconstruction left untreated or in relative obscurity. Accordingly, although the paper's treatment will have to have some overlaps with Kerr's (such as the critique of Kenny's critique of Aquinas), it will deal with issues essential to adequate replies to certain competent criticisms of his argument untreated by Kerr (such as Buridan's critique). For the sake of the "formally inclined" reader, the paper's treatment will also include an Appendix offering a formal reconstruction of both the main argument and its subarguments to demonstrate the formal rigor of Aquinas' original.

\section{REALNA RÓŻNICA AKWINATY I JEJ ROLA W KAUZALNYM DOWODZIE NA ISTNIENIE BOGA}

Streszczenie

Artykuł nie oferuje żadnej krytyki sposobu, w jaki Gaven Kerr rozpatruje argument Akwinaty. Zamiast tego daje alternatywną drogę rekonstrukcji tego argumentu, zamierzając wzmocnić zwłaszcza te jego kontrowersyjne aspekty, które Kerr pominął lub nie wyjaśnił gruntownie. W związ-

Causality and Skepticism about Causality, ed. Gyula Klima and Alexander W. Hall, Proceedings of the Society for Medieval Logic and Metaphysics, Vol. 10 (Cambridge: Cambridge Scholars Publishers, 2013), 31-42. 
ku z tym wprawdzie artykuł zawiera niektóre elementy tekstu Kerra (jak choćby krytyczne podejście do Kenny'a krytyki Akwinaty), przedstawia istotne kwestie związane z krytyką argumentu, których to kwestii Kerr nie poruszył (na przykład krytyka Buridana). Ze względu na czytelnika „o nachyleniu formalnym” artykuł zawiera także Dodatek, który przedstawia formalną rekonstrukcję zarówno głównego argumentu oraz jego kwestii szczegółowych w celu ukazania formalnej ścisłości pierwowzoru Akwinaty.

Przełożyt Jan Kłos

Key words: Aquinas's argument; Kerr's reconstruction; criticisms of Aquinas's argument; Kenny's critique of Aquinas; Buridan's critique.

Słowa kluczowe: argument Akwinaty; rekonstrukcja Kerra; krytyka argumentu Akwinaty; krytyka Burydana i Kenny’ego.

Informacje o Autorze: Dr GYULA KLIMA — profesor filozofii w Fordham University, New York, NY, USA; adres do korespondencji — e-mail: gyula.klima@gmail.com; ORCID: https://orcid.org/ 0000-0002-1597-7039.

\section{APPENDIX}

\section{The ReAl Distinction ARgument}

\begin{tabular}{|c|c|}
\hline 1. $(\exists \mathrm{x})(\sim \mathrm{Ix})$ & [intellectus essentiae argument \\
\hline 2. $(\mathrm{x})[\mathrm{Ix} \supset(\mathrm{y})(\mathrm{Iy} \supset \mathrm{x}=\mathrm{y})]$ & [uniqueness argument \\
\hline 3. (x) $[\sim \mathrm{Ix} \supset(\exists \mathrm{y})($ Cyx \& $\mathrm{x} \neq \mathrm{y} \&$ Iy) $]$ & [regress/universality argument \\
\hline 4. $(\exists y)[\operatorname{Iy} \&(x)(x \neq y \supset(\sim \operatorname{Ix} \&$ Cyx $))]$ & [conclusion \\
\hline 5. $(y)[\sim \operatorname{Iy} \vee(\exists x)(x \neq y \&(I x \vee \sim C y x))]$ & [neg. concl. \\
\hline 6. $\sim \mathrm{Ia}$ & {$[1, \mathrm{EI}: \mathrm{x} / \mathrm{a}$} \\
\hline 7. $(\exists y)($ Суa \& $a \neq y \&$ Iy) & [3, UI: x/a; 3,6, MP \\
\hline 8. Id & [7, EI: y/d, Simp. \\
\hline 9. $\mathrm{Cda}$ & [7, EI: y/d, Simp. \\
\hline 10. $a \neq d$ & [7, EI: y/d, Simp. \\
\hline 11. $(\mathrm{y})(\mathrm{Iy} \supset \mathrm{d}=\mathrm{y})$ & {$[2, \mathrm{UI}: \mathrm{x} / \mathrm{d}, 8,2, \mathrm{MP}$} \\
\hline 12. $\sim \operatorname{Id} \mid \quad(\exists x)(x \neq d \&(I x \vee \sim C d x))$ & {$[5, \mathrm{UI}: \mathrm{y} / \mathrm{d}$} \\
\hline 13. *8 | & {$[12, \mathrm{EI}: \mathrm{x} / \mathrm{c}, \mathrm{Simp}$.} \\
\hline 14. ---1 Ic & [12, EI: x/c, Simp., Disj. \\
\hline 15. $\mathrm{c}=\mathrm{d}[14,11, \mathrm{UI}: \mathrm{y} / \mathrm{c}, \mathrm{MP} \mid \mathrm{Ic}$ & [3, UI: x/c; IMP, EI: y/b; Simp \\
\hline 16. $* 13,15 \quad \mid \mathrm{c}=\mathrm{d}[15,11, \mathrm{UI}: \mathrm{y} / \mathrm{c}, \mathrm{MP}$ & $\neq \mathrm{c} \quad[3, \mathrm{UI}: \mathrm{x} / \mathrm{c} ; \mathrm{IMP}, \mathrm{EI}: \mathrm{y} / \mathrm{b} ; \mathrm{Sin}$ \\
\hline 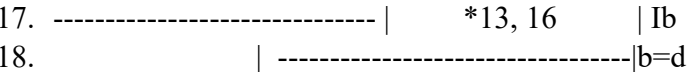 & $\begin{array}{l}\text { [3, UI: x/c; IMP, EI: y/b; Simp } \\
{[17,11, \text { UI: y/b, MP }}\end{array}$ \\
\hline $\begin{array}{l}\mid \mathrm{Cdc} \\
\quad * 19,14\end{array}$ & {$[15,18$, ID } \\
\hline
\end{tabular}

Key: ' $\mathrm{e}(\mathrm{x}){ }^{\prime}=$ esse of $\mathrm{x}$; ' $\mathrm{q}(\mathrm{x}){ }^{\prime}=$ quiddity of $\left.\mathrm{x} ; \mathrm{Ix}:=\mathrm{e}(\mathrm{x})=\mathrm{q}(\mathrm{x}) ; \sim \mathrm{Ix}:=\mathrm{e}(\mathrm{x}) \neq \mathrm{q}(\mathrm{x}) ;{ }^{\prime} \mathrm{K}(\mathrm{x})\right)^{\prime}:=\mathrm{x}$ is known 


\section{INTELLECTUS ESSENTIAE ARGUMENT}

(1) $(\exists \mathrm{x})[\mathrm{K}(\mathrm{q}(\mathrm{x})) \& \sim \mathrm{K}(\mathrm{e}(\mathrm{x}))]$

(2) $(\exists \mathrm{x})(\mathrm{e}(\mathrm{x}) \neq \mathrm{q}(\mathrm{x}))$

(3) $\mathrm{K}(\mathrm{q}(\mathrm{a})) \& \sim \mathrm{K}(\mathrm{e}(\mathrm{a}))$

(4) $(\mathrm{x})(\mathrm{e}(\mathrm{x})=\mathrm{q}(\mathrm{x}))$

(5) $\mathrm{q}(\mathrm{a})=\mathrm{e}(\mathrm{a})$

(6) $\mathrm{K}(\mathrm{q}(\mathrm{a})) \& \sim \mathrm{K}(\mathrm{q}(\mathrm{a}))$

(7) * [in some cases, essence is known, existence is not [conclusion

$[1, \mathrm{EI}$

[negation of conclusion

$[4, \mathrm{UI}$

$[3,5, \mathrm{SI}$

$[6$

\section{BURIDAN'S OBJECTION}

(1) $(\exists \mathrm{x})[\mathrm{K}(\mathrm{q}(\mathrm{x})$ qua $\mathrm{q}(\mathrm{x})) \& \sim \mathrm{K}(\mathrm{e}(\mathrm{x})$ qua $\mathrm{e}(\mathrm{x}))]$

[appellatio rationis

(2) $(\exists \mathrm{x})(\mathrm{e}(\mathrm{x}) \neq \mathrm{q}(\mathrm{x}))$

(3) $\mathrm{K}[\mathrm{q}(\mathrm{a})$ qua $\mathrm{q}(\mathrm{a}))] \& \sim \mathrm{K}[(\mathrm{e}(\mathrm{a})$ qua e(a) $]$

[assumption

(4) $\mathrm{q}(\mathrm{a})=\mathrm{e}(\mathrm{a})$

(5) $\mathrm{K}[\mathrm{q}(\mathrm{a})$ qua $\mathrm{q}(\mathrm{a}))] \& \sim \mathrm{K}[(\mathrm{q}(\mathrm{a})$ qua e(a) $]$

$[1, \mathrm{EI}: \mathrm{x} / \mathrm{a}$

$[\sim 2, \mathrm{UI}: \mathrm{x} / \mathrm{a}$

(6) $\sim *$

$[3,4$, SI

[no contradiction

AQUINAS' REPLY

$(\mathrm{x})[(\mathrm{e}(\mathrm{x})=\mathrm{q}(\mathrm{x})) \supset(\mathrm{K}(\mathrm{q}(\mathrm{x})$ qua $\mathrm{q}(\mathrm{x})) \supset \mathrm{K}(\mathrm{q}(\mathrm{x})$ qua $\mathrm{e}(\mathrm{x}))]$

“REVERSE” INTELLECTUS ESSENTIAE (INTELLECTUS EXISTENTIAE) ARGUMENT

(1) I know that I am, no matter what I am

(2) I do not know what I am, no matter what I am

(3) Therefore, that I am (my existence) is distinct from what I am (my essence)

\section{UNIQUENESS ARGUMENT (WHAT IS SIMPLE IS NOT COMPOSED FROM ESSE} AND FORM OR ESSE AND MATTER)

(4) $\quad(\mathrm{x})[\mathrm{Ix} \supset \mathrm{x} \neq(\mathrm{e}(\mathrm{x})+\mathrm{f}(\mathrm{x})) \& \mathrm{x} \neq(\mathrm{e}(\mathrm{x})+\mathrm{m}(\mathrm{x}))]$

(5) $\quad(\mathrm{x})(\mathrm{y})[(\mathrm{Ix} \&$ Iy \& $\mathrm{x} \neq \mathrm{y}) \supset \mathrm{x}=(\mathrm{e}(\mathrm{x})+\mathrm{f}(\mathrm{x})) \vee \mathrm{x}=(\mathrm{e}(\mathrm{x})+\mathrm{m}(\mathrm{x})]$

(6) $\quad \mathrm{x} \neq(\mathrm{e}(\mathrm{x})+\mathrm{f}(\mathrm{x})) \& \mathrm{x} \neq(\mathrm{e}(\mathrm{x})+\mathrm{m}(\mathrm{x})))^{\prime}={ }^{\prime} \sim \mathrm{Cx}$ ' [nominal def. of ' $\mathrm{Cx}$ ' $=$ 'complex'

(7) $\quad(\mathrm{x})[\mathrm{Ix} \supset \sim \mathrm{Cx}] \quad[1,3$

(8) $\quad(\mathrm{x})(\mathrm{y})[(\mathrm{Ix} \& \mathrm{Iy} \& \mathrm{x} \neq \mathrm{y}) \supset \mathrm{Cx}] \quad[2,3$

(9) $\quad(\mathrm{x})(\mathrm{y})[(\mathrm{Ix} \&$ Iy $) \supset \mathrm{x}=\mathrm{y}] \quad$ [conclusion

(10) $(\exists x)(\exists y)(I x \&$ Iy \& $\mathrm{x} \neq \mathrm{y}) \quad$ [neg. concl.

(11) Ia [7, EI: $x / a$, SIMP
[7, EI: $y /$ SIMP

(12) $\mathrm{Ib}$

[7, EI: $y / b$, SIMP

(13) $\quad a \neq b$

[7, EI: x/a, y/b, SIMP

(14) $\sim \mathrm{Ca}$

[4, UI: x/a, 4, 8, MP

(15) $\mathrm{Ca}$

(16) $*[11,12]$

$[5, \mathrm{UI}: \mathrm{x} / \mathrm{a}, \mathrm{y} / \mathrm{b}, 8,9,10, \mathrm{MP}$ 


\section{REGRESS ARGUMENT}

1. $(\mathrm{x})(\sim \mathrm{Ix} \supset(\exists \mathrm{y}) \mathrm{Cyx})$

2. $(\mathrm{x})\{\mathrm{Ix} \supset[(\mathrm{y}) \sim \mathrm{Cyx} \&(\mathrm{z})(\mathrm{x} \neq \mathrm{z} \supset \mathrm{Cxz})]\}$

3. $(\exists \mathrm{x}) \mathrm{Ix}$

4. $(\mathrm{x}, \mathrm{y}, \mathrm{z})(\mathrm{Cxy} \& \mathrm{Cyz} \supset \mathrm{Cxz})$

5. $(\mathrm{x}) \sim \mathrm{Cxx}$

6. $(\mathrm{x})[\sim \mathrm{Ix} \supset(\exists \mathrm{y})(\mathrm{Cyx} \& \mathrm{x} \neq \mathrm{y} \& \mathrm{Iy})]$

7. $(\exists \mathrm{x})[\sim \mathrm{Ix} \&(\mathrm{y})(\sim \mathrm{Cyx} \vee \mathrm{x}=\mathrm{y} \vee \sim \mathrm{Iy})]$

8. Id

9. $\sim \mathrm{Ia}$

10. (y) $(\sim \mathrm{Cya} \vee \mathrm{a}=\mathrm{y} \vee \sim \mathrm{Iy})$

11. $\sim \mathrm{Cda} \quad|\mathrm{a}=\mathrm{d} \quad| \sim \mathrm{Id}$

12. (y) $\sim(\mathrm{Cyd}) \mid * 8,9,11$ SI $\mid * 11,8$

13. $(\mathrm{z})(\mathrm{d} \neq \mathrm{z} \supset \mathrm{Cdz})$

14. $\mathrm{d}=\mathrm{a} \quad \mathrm{Cda}$

15. *8, $9,\left.14 \mathrm{SI}\right|^{*} 14,11$ [causal dependency of any $\sim \mathrm{Ix}$

[any Ix is an uncaused cause of everything else [no infinite regress in causes

[transitivity

[irreflexivity

[conclusion: premise 3 of main arg.

[neg. concl.

[3, EI: $\mathrm{x} / \mathrm{d}$

[7, EI: x/a, SIMP

[7, EI: x/a, SIMP

[10, UI: $y / d$

[2, 8, UI: x/d, MP, SIMP

- $[2,8, \mathrm{UI}: \mathrm{x} / \mathrm{d}, \mathrm{MP}, \mathrm{SIMP}$

[13, UI: z/a, IMP

\section{UNIVERSALITY ARGUMENT}

1. If there is not a most universal cause, then there is no most universal aspect of causation.

2. But there is a most universal aspect of causation, namely, being.

3. Therefore, there is a most universal cause (that is the cause of the being of everything other than itself).

\section{AQUINAS' ARGUMENT}

Whatever is not included in the understanding of an essence or quiddity is coming to it from outside, entering into composition with the essence; for no essence can be understood without its parts. But every essence can be understood without even thinking about its existence, for I can understand what a man or a phoenix is, and not know whether it actually exists in the nature of things. ${ }^{16}$ Therefore, it is clear that existence is distinct from essence, unless, perhaps, there is a thing whose quiddity is its own existence. And this thing would have to be unique and the first [being]. For something can only be multiplied either by the addition of some difference, as the nature of the genus is multiplied in the species, or on account of the reception of a form in diverse pieces of matter, as the nature of the species is multiplied in several individuals, or on account of one of the things multiplied being separate and the other received in something; for example, if there were some separate warmth, then it would be sepa-

${ }^{16}$ Despite modern presumptions to the contrary, Aquinas did not take a phoenix to be a merely fictitious, mythical bird by definition. Cf. Gyula KLIMA, "On Kenny on Aquinas on Being: A Critical Review of Aquinas on Being by Anthony Kenny," feature review in International Philosophical Quarterly 44 (2004): 567-80. So, for Aquinas, the phoenix is rather the illustration of a real, yet ephemeral natural phenomenon, much like a lunar eclipse or a rainbow, of which we may have the scientific definition (and thus we may know perfectly well its real essence, as opposed to merely knowing the meaning of its name), and yet we may not know whether its real essence is presently actualized in any actually existing individual. 
rate from a non-separate warmth [i.e., the warmth of a warm body] on account of its separation itself. However, if there were a thing that is existence only, so that it would be subsistent existence itself [ipsum esse subsistens], then this existence would not receive the addition of a difference, for then it would no longer be existence only, but existence and some form besides; and even less would it be receptive of the addition of matter, for then it would already be not subsistent, but material existence. Therefore, it remains that there can only be one thing that is its own existence. And so, in any other thing, the existence of the thing has to be other than its quiddity or nature or form. Therefore, the intelligences have to have existence besides their form, which is why it was said that an intelligence is form and existence.

Now, everything that a thing has ${ }^{17}$ is either caused in it by its own principles, as the ability to laugh in man, or it comes to the thing from an external source, as the light in the air is coming from the sun. But the existence of a thing cannot be caused by its form or quiddity itself (I mean, as by an efficient cause), for then a thing would be its own cause, and would bring itself into existence, which is impossible. Therefore, all such things, namely, those that have their existence as something distinct from their nature, have to have their existence from something else. However, since everything that is through something else [per aliud] is reduced to what is through itself [per se] as its first cause, there has to be something that is the cause of existence for everything, since it is existence only. For otherwise the series of causes would go to infinity, since everything that is not existence only has a cause for its existence, as has been said. It is clear, therefore, that an intelligence is both form and existence, and that it has its existence from the first being that is existence only; and this is the first cause, which is God. ${ }^{18}$

17 "Everything that a thing has" is implicitly contrasted with "what a thing is," i.e., what a thing is by its essence. For of course what a thing is by its essence is not caused in the thing either by intrinsic or by extrinsic principles. This is the reason why God, who is existence, is absolutely uncaused, whereas everything that merely has existence has to have it caused by something.

${ }^{18}$ Thomas Aquinas, "On Being and Essence" (selections from Thomas AQuinas, De Ente et Essentia). Translated by Gyula Klima in Medieval Philosophy: Essential Readings with Commentary, ed. Gyula Klima, Fritz Allhof, and Anand Jaypraksh Vaidya (Oxford: Blackwell, 2007), 240. 